\title{
OUTGROWTH AND MAINTENANCE OF NEURITES FROM CULTURED GOLDFISH RETINAL GANGLION CELLS
}

\author{
MICHAL SCHWARTZ and BERNARD W. AGRANOFF
}

Department of Biological Chemistry and Mental Health Research Institute, Neuroscience Laboratory Building, University of Michigan, Ann Arbor, Mich. 48109 (U.S.A.)

(Accepted July 31st, 1980)

Key words: goldfish - regeneration - ganglion cells - multiple processes - fasciculation

\section{SUMMARY}

Single retinal ganglion cells obtained from goldfish retina are shown to support outgrowth of neurites. Processes up to $1 \mathrm{~mm}$ in length grow out over a two week period from cells identified as retinal ganglion cells on the basis of morphological criteria, in the absence of supporting elements. Prior crush of the optic nerve significantly enhances neuritic outgrowth. Fibers emerging from single cells often associate to form a single process. A tendency for characteristic clockwise patterning of neurite outgrowth from single cells is seen, similar to that obtained from retinal explants.

\section{INTRODUCTION}

The goldfish retinal ganglion cell has been demonstrated to undergo a series of characteristic morphological changes following optic nerve disruption. Radioautographic studies indicate increased RNA ${ }^{21}$ and protein labeling ${ }^{13}$. Biochemical studies on whole retina indicate increased RNA precursor metabolism and RNA labeling4. Retinal tubulin messenger activity is increased ${ }^{5}$, as is labeling of tubulin ${ }^{14}$. It is inferred on the basis of the histological findings that these various increases are confined to ganglion cells. While large in size, these cells are a numerically small fraction of the total retinal cell population ${ }^{10,13}$. Other studies have demonstrated that optic nerve crush greatly enhances the ability of retinal explants to send out neurites ${ }^{18}$. While it can be shown that the ganglion cells within the explant are the source of the neurites ${ }^{16}$, it has not previously been shown whether the presence of other retinal elements is necessary for expression of the outgrowth. To clarify this question, we have examined isolated ganglion cells from control retinas as well as from retinas whose optic nerve had previously been crushed, under in vitro culture conditions. 


\section{MATERIALS AND METHODS}

Goldfish (Carassius auratus) 6-7 cm in body length, supplied by Ozark Fisheries (Stoutland, Mo.) underwent intraorbital crush of the right optic nerve as previously described ${ }^{19}$.

\section{Culture of dissociated retinal cells}

Five to 10 retinas were removed from fish whose optic nerve had been crushed 10-14 days before as previously described ${ }^{18,19}$, and incubated in 1-2 $\mathrm{ml}$ of phosphatebuffered salts (PBS, prepared according to Dulbecco ${ }^{9}$ ) containing $1 \mathrm{mg} / \mathrm{ml}$ of hyaluronidase (Sigma) for removal of the vitreous. Following this treatment the retinas were rinsed and then incubated for an additional $10 \mathrm{~min}$ in a PBS solution free of $\mathrm{Ca}^{2+}$ and $\mathrm{Mg}^{2+}$ and containing $0.25 \%$ trypsin (Sigma). After the last incubation, the treated retinas were washed with $\mathrm{Ca}^{2+}$ - and $\mathrm{Mg}^{2+}$-free PBS and then transferred into Leibowitz nutrient medium supplemented with HEPES (N-2-hydroxyethylpiperazine- $\mathrm{N}^{\prime}$-ethanesulfonic acid, $\mathrm{pH} \mathrm{7.2)} \mathrm{and} 10 \%$ fetal calf serum (FCS) in the presence of gentamycin sulfate $(0.1 \mathrm{mg} / \mathrm{ml}), 5^{\prime}$-fluorodeoxyuridine $\left(5^{\prime}-\mathrm{FudR}, 0.1 \mathrm{mM}\right)$ and uridine $(0.2 \mathrm{mM})$. The treated retinas were then dissociated mechanically by gently pipetting the tissue up and down through a Pasteur pipette. The suspension was allowed to settle for 10-15 min and the supernatant was collected. In early experiments the treated retinas were forced through a metal mesh (stainless steel, 60 mesh, 30\% open, Small Parts, Inc., Miami, Fla.) to remove clumps, but the procedure did not sufficiently remove them to compensate for the resulting reduction in cell yield. Cells were counted in a hemocytometer after staining with Trypan blue ${ }^{24}$. About $10^{6}$ cells suspended in $1 \mathrm{ml}$ of medium were cultured in a dish with poly-L-lysine-coated substratum ${ }^{15}$. These experiments employed either Nunc plastic dishes or dishes whose bottoms were removed and substituted by cemented round glass coverslips (no. 1-1/2, $33 \mathrm{~mm}$ ).

\section{Fluorescent studies}

The cells were labeled with a phospholipid-like fluorophore (dioctadecylindocarbocyanine, (dil) ${ }^{2}$, by incubating the cell culture for $10 \mathrm{~min}$ at $37^{\circ} \mathrm{C}$ in $1 \mathrm{ml}$ of PBS to which $5 \mu \mathrm{l}$ of ethanolic diI $(0.3 \mathrm{mg} / \mathrm{ml})$ had been added. The cells were then rinsed several times in PBS and examined in a Leitz Diavert microscope using 40 or $100 \times$ epiillumination objectives.

\section{Electron microscopy}

Cultures were fixed for $60 \mathrm{~min}$ in $3.5 \%$ glutaraldehyde in L-15 medium, washed with L-15 and post-fixed for $30 \mathrm{~min}$ in $2 \%$ osmium tetroxide, then dehydrated in ascending ethanol concentrations (30-100\%) and embedded in Spurr (Polysciences, Warrington, $\mathrm{Pa}$ ) as described by $\mathrm{De}$ Boni et al. ${ }^{7}$.

\section{RESULTS}

The total yield of dissociated cells from post-crush retina ranged from $2 \times 10^{6}$ to $8 \times 10^{6}$ cells/retina. After a few days in culture, progressive deterioration of most 
cellular elements occurred, while those judged to be ganglion cells survived and eventually constituted the predominant remaining viable cells in the culture. Occasional clumps of cells and debris were seen, and presumably represented undissociated and reassociated cells. One million freshly dissociated cells, 80-91\% of which appeared viable on the basis of Trypan blue exclusion, were added to individual culture dishes. Adherent cells were identified as presumptive ganglion cells on the basis of size (8-14 $\mu \mathrm{m})$ and nucleolar prominence and number. Approximately 500 cells with processes could eventually be identified per dish, and their positions were determined by means of microscope stage coordinates. After $24 \mathrm{~h}$ in culture, ganglion cells that would ultimately send out neurites showed multiple outgrowths (Fig. 1), most of which were eventually replaced by one or more distinct processes (Fig. 2). As indicated below, many such processes are composed of multiple individual fibers. About one-half of the cells observed after 7 days in vitro had single processes, a third had two processes, and the remainder had 3-6 separate processes. Nomarski interference contrast photomicrographs verified that the processes were outgrowths of single ganglion cells containing a round eccentric nucleus with one (Fig. 3) or more prominent nucleoli (Fig. 4),

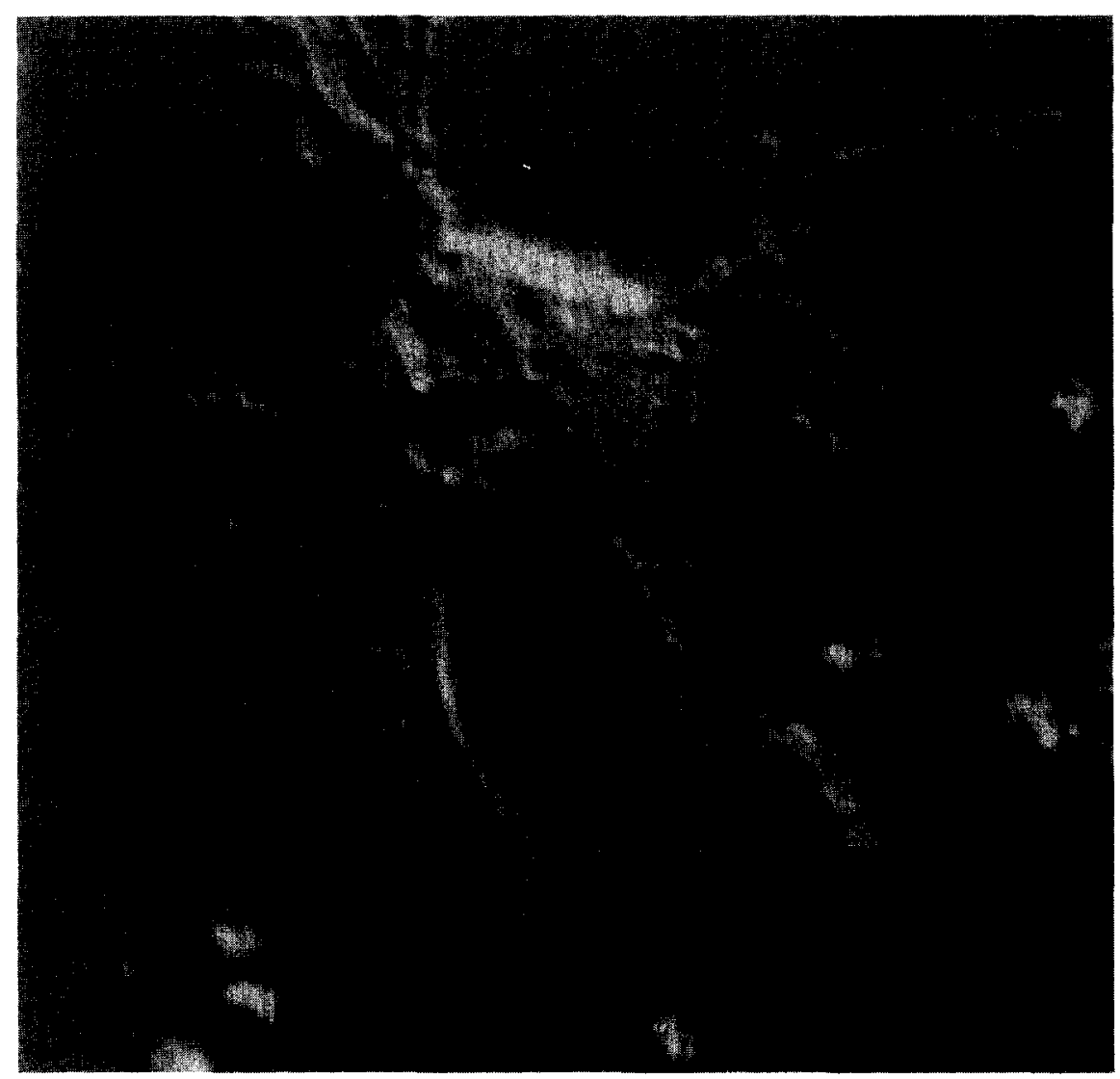

Fig. 1. Single retinal ganglion cell in vitro at an early stage $(24 \mathrm{~h})$, showing multiple outgrowths. Nomarski interference micrograph. Bar $=3.75 \mu \mathrm{m}$. 
as was noted in ganglion cells in situ following optic tract section ${ }^{23}$. Varicosities on the processes (e.g. Fig. 4) are typical of those seen in regenerating optic nerve in vivo and/or retinal explant neurites in vitro ${ }^{30}$.

By both interference contrast and fluorescence microscopy following the addition of a fluorescent lipophilic dye (Fig. 5), it was apparent that while individual fibers often branch distally, in many instances they arose from the cell body as multiple fibers. The individual fibers show a marked tendency to wrap around each other (Figs. 3 and 5 ), and the majority of processes longer than $100 \mu \mathrm{m}$ also demonstrate a tendency to grow more in a clockwise direction (Figs. 2B, D and 3), than to grow out straight or counterclockwise. Out of a sample of 50 long processes, 40 had grown in a clockwise manner, 2 appeared counterclockwise, and 8 showed neither tendency.

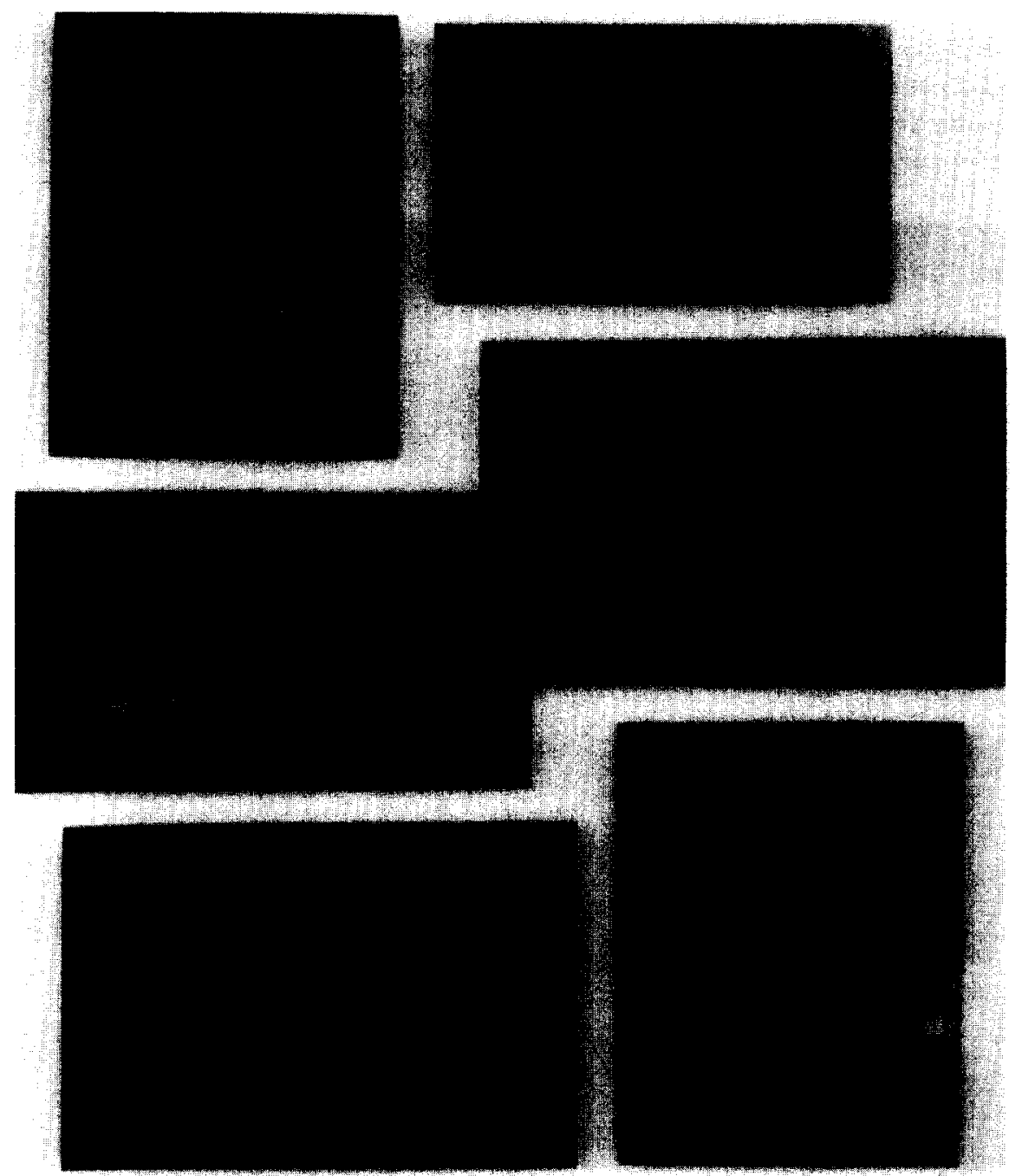

Fig. 2. Phase micrographs of single retinal ganglion cells in culture. A : cell aggregate. B: two processes growing out of the same cell. $C$ : distal branching. $D$ and $E$ : multiple processes emerging from one cell body. Bar in $\mathrm{A}-\mathrm{C}=23.3 \mu \mathrm{m}$ and in $\mathrm{D}$ and $\mathrm{E}=14 \mu \mathrm{m}$. 


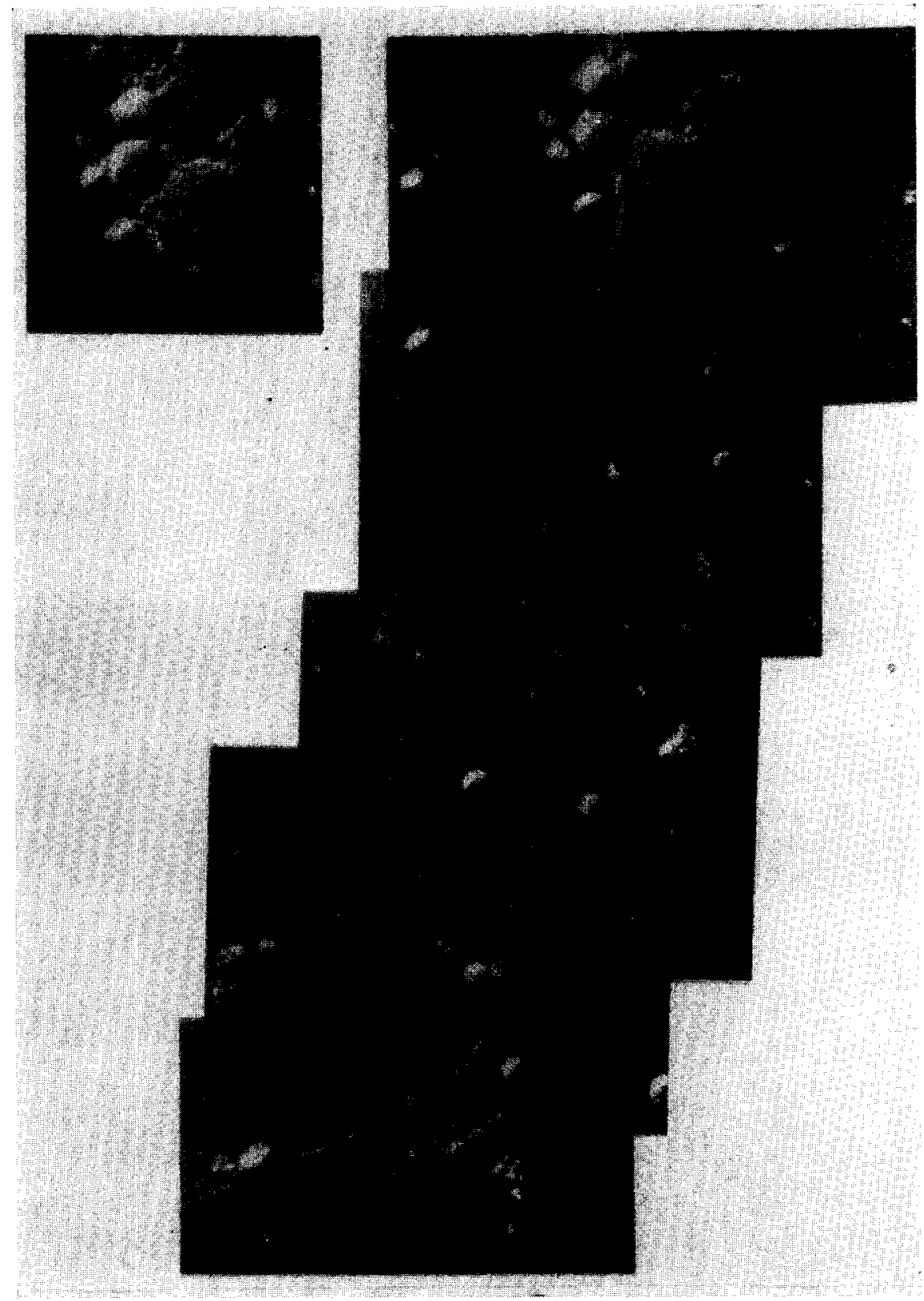

Fig. 3. Nomarski interference micrograph of a single retinal ganglion cell in vitro showing a single process composed of more than one fiber. Separation of fibers is apparent (asterisks). Insert: the cell bo$\mathrm{dy}$, focussed to show eccentric nucleus and prominent nucleolus (arrow), as well as adherent cellular debris. $\mathrm{Bar}=3.75 \mu \mathrm{m}$. 


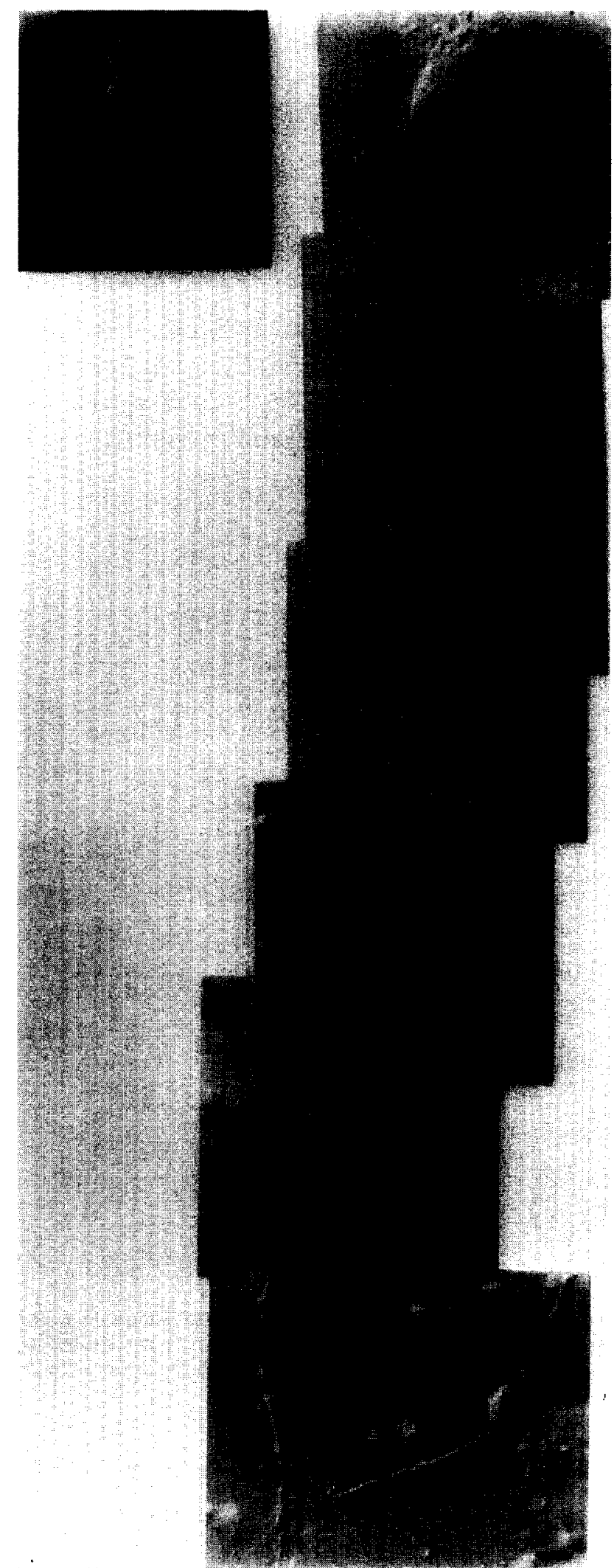

Fig. 4. Nomarski interference micrograph of a single retinal ganglion cell, showing distal branching, varicosities and the growth cone. The inserted micrograph shows the cell refocussed revealing two nucleoli (arrows). Bar $=3.75 \mu \mathrm{m}$. 


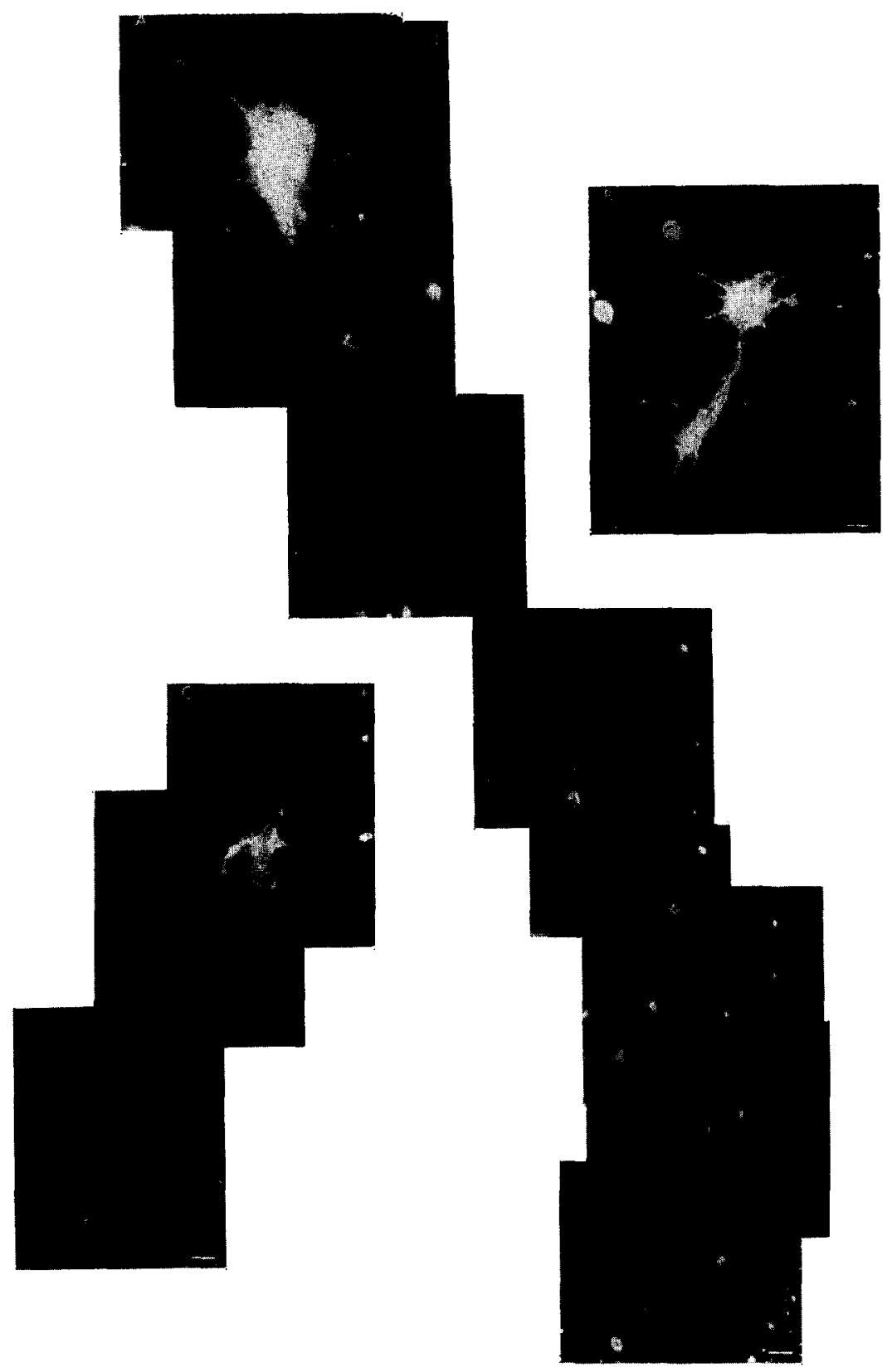

Fig. 5. Fluorescence photomicrographs of retinal ganglion cells in culture stained with the lipophilic dye, diI. A : spiralling of the fibers within the single cell process with distal branching. Bar $=4.6 \mu \mathrm{m}$. B: multiple outgrowths from the same cell body with one major process composed of several fibers. Bar $=4.6 \mu \mathrm{m}$. C: two processes growing out of one cell. Bar $=7 \mu \mathrm{m}$. Varicosities are seen on one process; the other shows distal branching. 


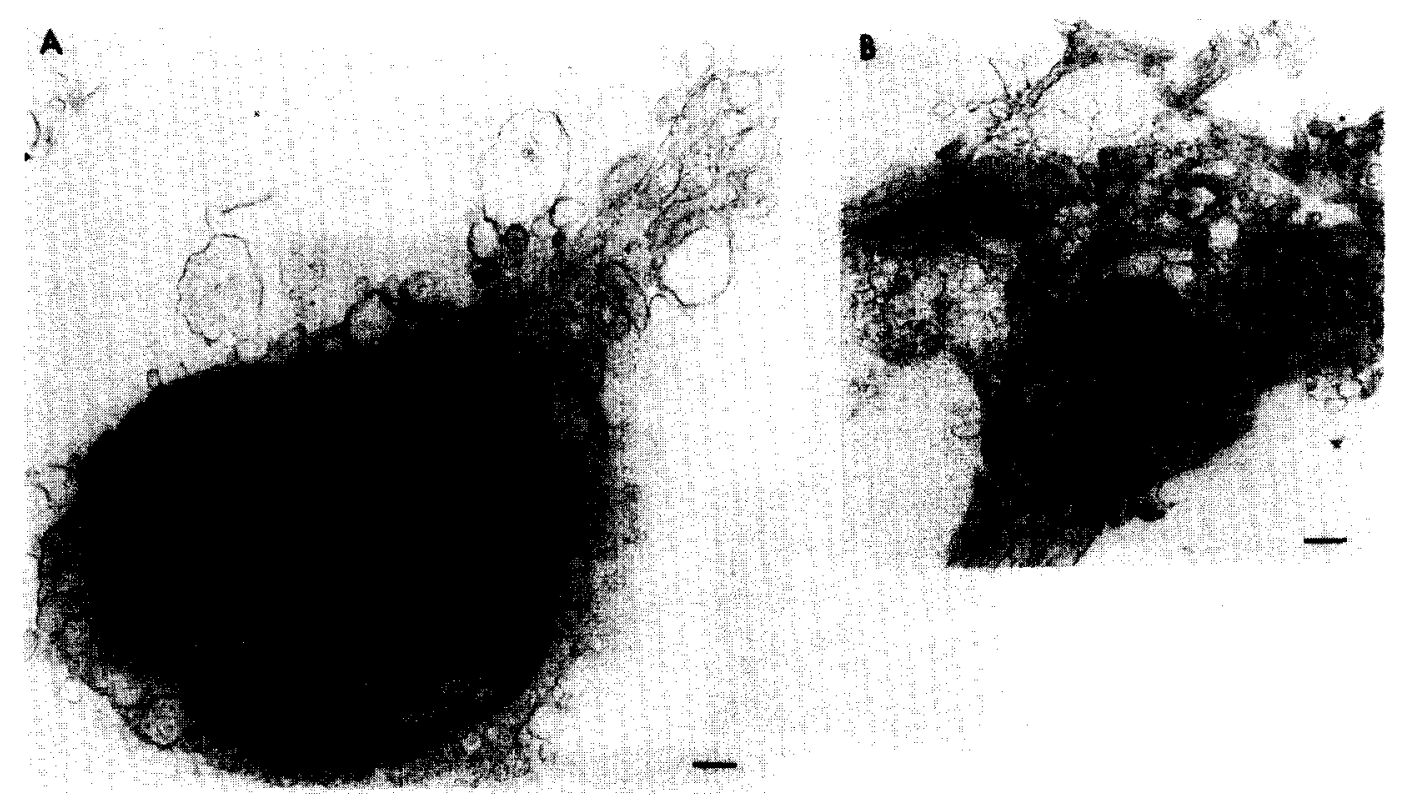

Fig. 6. A : electron micrograph of a ganglion cell in dissociated retinal cultures obtained from postcrush retina. Note a large nucleus and small area of cytoplasm $(\times 27,300)$. Bar $=0.4 \mu \mathrm{m}$. B: growth cone at the growing tip of a process emerging from a single cell $(\times 12,200)$. Bar $=0.83 \mu \mathrm{m}$.

Electron micrographs taken from ganglion cells after 2 weeks in culture demonstrate a large nucleus with one or more prominent nucleoli and relatively little cytoplasm (Fig. 6A). Similar observations were reported for isolated goldfish retinal ganglion cells by Giulian ${ }^{10}$ and by Turner et al. ${ }^{29}$ for newt retinal ganglion cells in vivo. The emergence of multiple fibers from a single cell body is shown in Fig. 7.

Previous studies indicated that crush of the optic nerve resulted in enhanced outgrowth of processes from retinal explants ${ }^{18}$. The dissociated cell preparation enabled us to further study the effect of a conditioning lesion on outgrowth from the ganglion cells in culture. Results based on subsequent growth from all the adherent cells which were identified as ganglion cells, indicated that $77.2 \% \pm 13.9$ of adherent ganglion cells derived from post-crush retina eventually sent out processes, compared with only $31.3 \% \pm 6.7$ from ganglion cells from control retinas. The summed process length outgrowing from individual ganglion cells in culture was measured as a function of days in culture (Fig. 8). Initially, ganglion cells derived from post-crush retina showed a higher outgrowth rate. Ganglion cells derived from normal retina, however, remained viable longer, and after two weeks in culture, significant continuing growth was apparent. After 30 days in vitro, ganglion cells derived from control retina appeared viable, while processes from ganglion cells derived from post-crush retina showed evidence of deterioration. 


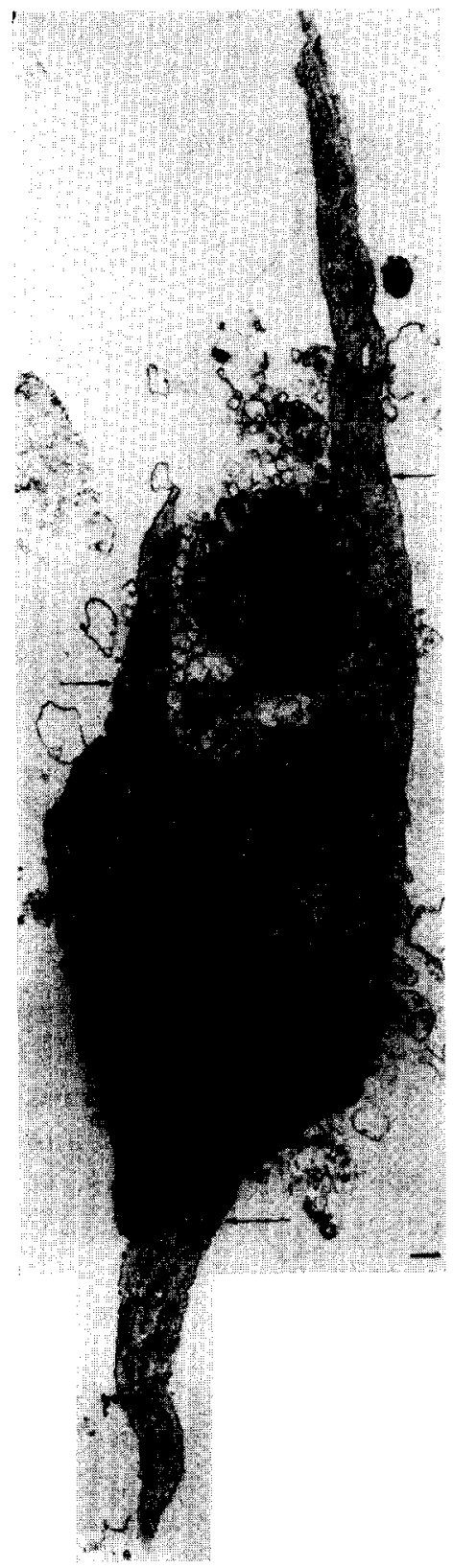

Fig. 7. Multiple processes (arrows) growing out of a single ganglion cell in culture $(\times 14,300)$. Bar $=$ $0.71 \mu \mathrm{m}$. 


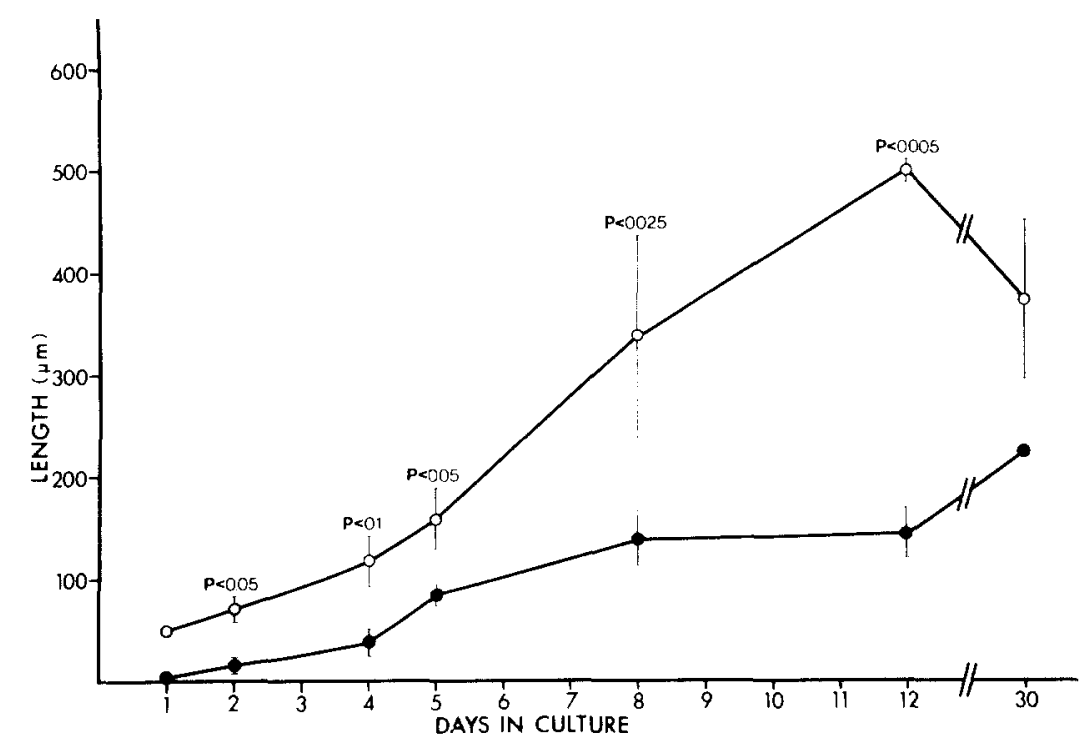

Fig. 8. Pattern of elongation of processes emerging from dissociated ganglion cell in culture obtained from ( ) post-crush retina and from (O) control retina. Results represent average length of at least 10 processes at each time point.

\section{DISCUSSION}

The goldfish retinal ganglion cell has been demonstrated to respond to axotomy and to eventually regenerate its cut axon with little apparent alteration in other retinal elements ${ }^{12}$. In the explanted goldfish retina, the ganglion cells have been demonstrated to be the source of outgrowing neurites ${ }^{16,17}$. In fact, under extended explant culture conditions, other retinal cellular elements degenerate, while the ganglion cells survi$\mathrm{ve}^{16}$. Identification of neurite-bearing cells as ganglion cells was made on the basis of the microscopic appearance of adherent cells. Since adhesion is a prerequisite for neuritic outgrowth, the study does not rule out the possibility that other retinal cells could support neuritic outgrowth had they adhered. Inferential confirnation of neuritic outgrowth from ganglion cells rests on the previous explant studies. Direct confirmation awaits the availability of more specific cell markers. Although these observations suggested that the ganglion cell can survive in vitro, it was less clear prior to the present study that the ganglion cells can also initiate axonal growth in vitro, in the absence of supporting cells.

Various disruptive techniques, including enzymatic digestion and dissociation have been employed to obtain identified retinal cells from a number of species, including marine teleosts ${ }^{8}$, reptiles ${ }^{1}$, amphibia ${ }^{3}$ and rats $^{26}$. Recently, ganglion cells from goldfish have been isolated by dissection ${ }^{10}$. While ganglion cells are reported to constitute only $5 \%$ of the total cells in the retina, in post-crush retina they are the largest cells, a factor which should facilitate their isolation by physical techniques. Their differential survival in cultured retinal explants suggested that this property would also be 
useful in procedures for their enrichment. While various markers have been proposed for ganglion cells in other species, for the present we rely on the morphological appearance of the cultured cells and on their in vitro properties, i.e. to send out neurites and perhaps thereby to adhere to the substratum, and to survive in vitro, as confirmatory criteria. The present results give evidence that ganglion cells in the absence of supporting retinal elements can initiate and maintain outgrowth of processes. Like the regenerating neurites seen in vivo and in retinal explants in vitro, neurites from cultured ganglion cells are characterized by the presence of varicosities, which are not seen in the normal nerve. Multiple processes, originating at the cell body, as well as distal branching of individual processes were observed at the light (Figs. 2-5) and electron microscopic level (Fig. 7). Distal branching of axons of the normal cat optic nerve has been observed in horseradish peroxidase studies ${ }^{20}$. The presence of branching and increased fiber numbers has long been known to occur in regenerating peripheral nerves $^{6,27}$. Since CNS regeneration occurs in teleosts, we might anticipate branching in the regenerating goldfish optic nerve. In fact, Murray and Battisti22 recently demonstrated that the number of fibers in the regenerating goldfish optic nerve is increased over that normally seen. The emergent multiple fibers and distal branching seen in the present study may thus be a property of the early regenerative response, although possible unphysiological aspects of in vitro conditions must also be considered.

A tendency of fibers from a single cell to associate and wrap about one another was apparent by phase and interference contrast microscopy as well as by fluorescence microscopy of stained cells, although frank spiralling of fibers seen in fascicles emerging from explants was not prominent. While Vinnikov reported spiralling of 'neurofibrillae' optic nerve fibers of the adult crucian carp retina ${ }^{30}$, it is possible that the differential adhesiveness between fibers relative to that for the poly-lysine substratum is insufficient to permit full expression of this tendency in the single cell preparation.

The importance of fiber association in manifestation of the fasciculation of nerves seen in vivo, and of the role of fasciculation in fiber guidance has previously been discussed ${ }^{11,25}$. Roles for glial cells in nerve fasciculation ${ }^{7}$ and for a specific protein (CAM) have been proposed ${ }^{28}$. The previously observed tendency for processes to grow out in a clockwise fashion is likely related to the tendency to fasciculate - both are believed to reflect a postulated intrinsic helicity of individual fibers ${ }^{15}$.

While the ganglion cells and their processes behave much as might be expected from consideration of the previous explant culture studies, there are also some interesting differences. The outgrowth of neurites from single cells is sustained for several weeks while elongation of neurites from post-crush explants is minimal after the first week in culture. Furthermore, single ganglion cells derived from control retinas survive longer than post-crush ganglion cells, and their outgrowths even appear to 'catch up' after several weeks in culture. This catch up of the control retinal explant does not occur $^{18}$.

On the basis of cell counts and estimates of ganglion cells in the retina, only about $1 \%$ of the ganglion cells initially present in the post-crush retina adhere and extend neurites. This number is significantly lower in control retina, even after several days of observation. It should be emphasized that the ganglion cells in post-crush reti- 
na are significantly larger than those in the control retina, although the latter show indications of hypertrophy after several days of culture in vitro ${ }^{18}$. It is not possible to state on the basis of the present observations whether this apparent decrease can be attributed to differences of ganglion cell populations which adhere to the substratum or in the intrinsic potential for outgrowth. Further refinements in isolation techniques will be required to answer this question. Nevertheless, the availability of growing ganglion cells provided by this technique should prove useful in further studies on the response of ganglion cells to axotomy and the requirements for neurite outgrowth, extension and maintenance.

\section{ACKNOWLEDGMENTS}

This research was supported by Grant NS 13743. Dr. Michal Schwartz was supported by a fellowship from the Weizmann Institute of Science, Rehovot, Israel. We thank Mr. Mark McGinnis and Ms. Debbie DeHaan for their excellent technical assistance.

\section{REFERENCES}

I Anctil, M., Ali, M. A. and Couillard, P., Isolated retinal cells of some lower vertebrates, Rev. Canad. Biol., 32 (1973) 107-119.

2 Axelrod, D., Wight, A., Webb, W. and Horwitz, A., Influence of membrane lipids on acetylcholine receptor and lipid probe diffusion in cultured myotube membrane, Biochemistry, 17 (1978) 3604-3609.

3 Bader, C. R., MacLeish, P. R. and Schwartz, E. A., Responses to light of solitary rod photoreceptors isolated from tiger salamander retina, Proc. nat. Acad. Sci. (Wash.), 75 (1978) 3507-3511.

4 Burrell, H. R., Dokas, L. A. and Agranoff, B. W., RNA metabolism in the goldfish retina during optic nerve regeneration, $J$. Neurochem., 31 (1978) 289-298.

5 Burrell, H. R., Heacock, A. M., Water, R. D. and Agranoff, B. W., Increased tubulin messenger RNA in the goldfish retina during optic nerve regeneration, Brain Research, 168 (1979) 628-632.

6 Cajal, S. Ramón y., Degeneration and Regeneration of the Nervous System, Oxford Univ. Press, London, 1928.

7 De Boni, U., Seger, M., Scott, J. W. and Crapper, D. R., Neuron culture from adult goldfish, $J$. Neurobiol., 7 (1976) 495-512.

8 Drujan, B. D. and Svaetichin, G., Characterization of different classes of isolated retinal cells, Vision Res., 12 (1972) 1777-1784.

9 Dulbecco, R. and Vogt, M., Plaque formation and isolation of pure lines with poliomyelitis viruses, J. exp. Med., 99 (1954) 167-199.

10 Giulian, D., Isolation of ganglion cells from the retina, Brain Research, 189 (1980) 135-155.

11 Goldberg, S. and Frank, B., The guidance of optic axons in the developing and adult mouse retina, Anat. Rec., 193 (1979) 763-774.

12 Grafstein, B. and McQuarrie, I. G., Role of the nerve cell body in axonal regeneration. In C. W. Cotman (Ed.), Neuronal Plasticity, Raven Press, New York 1978, pp. 155-195.

13 Grafstein, B. and Murray, M., Transport of protein in goldfish optic nerve during regeneration, Exp. Neurol., 25 (1969) 494-508.

14 Heacock, A. M. and Agranoff, B. W., Enhanced labeling of a retinal protein during regeneration of optic nerve in goldfish, Proc. nat. Acad. Sci. (Wash.), 73 (1976) 828-832.

15 Heacock, A. M. and Agranoff, B. W., Clockwise growth of neurites from retinal explants, Science, 198 (1977) 64-66.

16 Johns, P. R., Heacock, A. M. and Agranoff, B. W., Neurites in explant cultures of adult goldfish retina derive from ganglion cells, Brain Research, 142 (1978) 531-537.

17 Johns, P. R., Yoon, M. G. and Agranoff, B. W., Directed outgrowth of optic fibers regenerating in vitro, Nature (Lond.), 271 (1978) 360-362. 
18 Landreth, G. E. and Agranoff, B. W., Explant culture of adult goldfish retina: effect of prior optic nerve crush, Brain Research, 118 (1976) 299-303.

19 Landreth, G. E. and Agranoff, B. W., Explant culture of adult goldfish retina: a model for the study of CNS regeneration, Brain Research, 161 (1979) 39-53.

20 Mason, C. A. and Robson, J. A., Morphology of retino-geniculate axons in the cat, Neuroscience, 4 (1979) 79-97.

21 Murray, M., ${ }^{3} \mathrm{H}$-Uridine incorporation by regenerating retinal ganglion cells of goldfish, Exp. Neurol., 39 (1973) 489-497.

22 Murray, M. and Battisti, W., Regeneration of optic nerve axons and their terminals in goldfish, Neurosci. Abstr., 5 (1979) 681 (abstract 2317).

23 Murray, M. and Grafstein, B., Changes in the morphology and amino acid incorporation of regenerating goldfish optic neurons, Exp. Neurol., 23 (1969) 544-560.

24 Phillips, H. J., Dye exclusion test for cell viability. In P. F. Kruse and M. K. Patterson (Eds.), Tissue Culture Methods and Application, Academic Press, New York, 1973, pp. 406-408.

25 Rutishauser, U., Gall, W. E. and Edelman, G. M., Adhesion among neural cells of the chick embryo. IV. Role of cell surface molecule CAM in the formation of neurite bundles in culture of spinal ganglia, J. Cell Biol., 79 (1978) 382-393.

26 Sarthy, P. V. and Lam, D. M. K., Isolated cells from a mammalian retina, Brain Research, 176 (1979) 208-212.

27 Shawe, G. D. H., On the number of branches formed by regenerating nerve fibres, Brit. J. Surg., 42 (1954) 474-488.

28 Thiery, J.-P., Brackenbury, R., Rutishauser, U. and Edelman, G. M., Adhesion among neuronal cells in chick embryo, Cell. Neurobiol., (1977) 199-206.

29 Turner, J. E., Delaney, R. K. and Powell, R. E., Retinal ganglion cell response to axotomy in the regenerating visual system of the newt (Triturus viridescens): an ultrastructural morphometric analysis, Exp. Neurol., 62 (1978) 444-462.

39 Vinnikov, J. A., Transformations of retinal ganglionic cells in tissue cultures, Nature (Lond.), 158 (1946) 377. 